RYSZARD POLAK

ORCID: 0000-0002-5617-2333

Akademia Wychowania Fizycznego Józefa Piłsudskiego w Warszawie

Filia w Białej Podlaskiej

\title{
Kościół katolicki i neopogaństwo niemieckie w myśli Leona Halbana
}

\section{Uwagi wstępne}

Spośród postaci żydowskiego pochodzenia wiele było wybitnych i zasłużonych dla polskiego życia naukowego i społecznego. Nie jest więc prawdą, że osoby mające przodków wywodzących się z kultury, w której obowiązującą religią był judaizm, były na pewno zwolennikami permisywnego komunizmu czy socjalizmu lub anarchistami albo kosmopolitami, a ich życie i praca w niepodległej Polsce stały się po 1918 roku ciężarem, społeczeństwo polskie zaś wrogiem ich narodowej odrębności i niezależności. Do takich ludzi — pozytywnie zasłużonych dla naszego kraju — należał lwowski, a potem lubelski profesor prawa Leon Halban (23 września 1893-3 maja 1960).

\section{Rodzina i życie Leona Halbana}

Leon Halban urodził w Krakowie, i z tym miastem — podobnie jak jego przodkowie - początkowo związał swoje życie. Jego dziadek Leon Blumenstock (1838-1897) był profesorem medycyny sądowej na Wydziale Lekarskim Uniwersytetu Jagiellońskiego w Krakowie. Jak pisał Jan Widacki, kariera naukowa i życie osobiste tego lekarza i prawnika były wielokrotnie już za jego życia oraz po śmierci przedmiotem kontrowersyjnych komentarzy i polemik zarówno wśród uczonych, jak i „,zwyczajnych” mieszkańców miasta. Podkreślano między innymi, że L. Blumenstock uzyskał habilitację z zakresu prawa, mimo że nigdy tej dziedziny wiedzy nie studiował. Przyznawano natomiast, że był on dosyć kompetentnym biegłym z zakresu medycyny sądowej i opiniował trafnie różne przypadki zabójstw dokonywanych w jego czasach w Krakowie, a jego dorobek w dziedzinie medy- 
cyny sądowej nie był raczej kwestionowany. Krytycznie zaś oceniano jego życie moralne. Złożyło się na to kilka faktów, spośród których na szczególną uwagę zasługują dwa. Po pierwsze, co prawda w 1880 roku — będąc wcześniej wyznawcą judaizmu — przeszedł na wiarę katolicką oraz zmienił nazwisko na Halban; jednak w kręgach, w których się obracał, nie był identyfikowany jako katolik, lecz jako osoba indyferentna religijnie i moralnie słaba, która konwersji religijnej dokonała jedynie ze względu na chęć zrobienia kariery naukowej. Również powszechnie dyskutowano wśród jego znajomych fakt, że przyczyną jego szybko postępującej choroby oraz potem przedwczesnej śmierci było zarażenie się kiłą w krakowskiej „,nocnej kawiarni”"; prowadził więc niemoralne życie, co uznane zostało przez jego uniwersyteckich kolegów za niegodne uczonego i katolika.

O wiele lepszą opinię w polskim społeczeństwie miał jego brat Henryk (18451902). Był on $z$ wykształcenia prawnikiem ${ }^{2}$. Pisał po niemiecku prace popularyzujące polską literaturę i kulturę 3 ; z zawodu zaś był urzędnikiem państwowym zatrudnionym przy austriackiej Radzie Ministrów. Małżonka Henryka była siostrą socjaldemokratycznego polityka W. Adlera. Henryk, podobnie jak jego brat Leon, otrzymał od cesarza Franciszka Józefa I tytuł szlachecki i prawo używania nazwiska Halban. W tym samym czasie obydwaj panowie zmienili wyznanie na katolickie.

Ojciec zaś naszego uczonego - Alfred — był historykiem prawa. Pełnił w latach 1919/1920 funkcję rektora Uniwersytetu Jan Kazimierza we Lwowie i wykładał filozofię prawa na tej uczelni. On także dobrze zasłużył się dla nauki i kultury polskiej, zwłaszcza w trudnych czasach braku niepodległości naszego kraju. Napisał także wiele wartościowych z punktu widzenia badacza dziejów dyscyplin, którymi się zajmował, prac, zarówno w języku polskim ${ }^{4}$, jak i niemieckim ${ }^{5}$.

1 J. Widacki, Szkice z dziejów prawa karnego i kryminologii w Krakowie. Myśli i ludzie, Kraków 2014, s. 75-81.

${ }^{2} \mathrm{Z}$ prac z zakresu prawa wydał między innymi Kryminat krakowski wobec noweli karnej z d. 15 listopada 1867 r., Kraków 1868.

3 Zob. na przykład H. Blumenstock, Die Ukraine und Ihre Dichter Bohdan Zaleski, Wien 1877; Die Sommernacht, Wien 1881; Graf Alfred Potocki, Wien 1889. Pod nazwiskiem L. Halban opublikował między innymi Polen und das Jahr 1863, Wien 1893.

${ }^{4}$ Zob. A. Blumenstok [przed zmianą nazwiska na polskie - R.P.], Kilka słów o prawnym charakterze interdyktu kościelnego: przyczynek do prawa karnego kanonicznego, Kraków 1886; idem, Opieka papieska w wiekach średnich, Kraków 1889; idem, Plany reform skarbowo-wojskowych w pierwszej połowie panowania Zygmunta Starego, Lwów 1888; idem, Studyja nad historyja własności nieruchomej u ludów germańskich. 1. Stosunek człowieka do ziemi u Franków salickich przed wkroczeniem na terytorium rzymskie, Kraków 1891; idem, Wiadomość o rękopisach prawno-historycznych Biblioteki Cesarskiej w Petersburgu: sprawozdanie z poszukiwań, Kraków 1891; idem, Zbiór kanonów paryskiej bibijoteki św. Gertrudy, Kraków 1891; A. Halban, Rzym i Germanien, „Ateneum” 4, 1897, z. 2, [Warszawa], s. 265-311; idem, W sprawie reformy nauki prawa, [Lwów 1902]; idem, Rodowód państwowości, Lwów 1925; idem, Wpływy obce jako samodzielny przedmiot badań w zakresie prawa, Lwów 1925; A. Halban, K. Sochaniewicz, Nauczanie historji w szkołach średnich jako przygotowanie do studium uniwersyteckiego wogóle, a historycznego i prawniczego w szczególności, Lwów 1925.

5 Zob. A. Halban-Blumenstok, Die canonistischen Handschriften der Kaiserlichen Öffentlichen Bibliothek in St. Petersburg, Leipzig 1895; A. Halban, Entstehung des deutschen Immobili- 
Warto także zasygnalizować, że prababka Leona Halbana (ze strony matki) — Zofia z Chodźków — była siostrą konsula rosyjskiego w Persji, Aleksandra (1804-1891), znanego orientalisty i profesora slawistyki w Collège de France. Matka z kolei była bratanicą Włodzimierza Spasowicza (1829-1906), który był, jak powszechnie wiadomo, naukowcem, prawnikiem i historykiem literatury o orientacji pozytywistycznej.

Bohater niniejszego artykułu, Leon Halban, uczęszczał do szkoły powszechnej w Czerniowcach, a następnie do gimnazjum we Lwowie. Przed pierwszą wojną światową (1911-1914) ukończył studia prawnicze na Uniwersytecie Jana Kazimierza we Lwowie, a następnie kontynuował naukę prawa na Uniwersytecie Wiedeńskim w latach 1914-1915. W 1916 roku uzyskał doktorat we Lwowie, później zaś pracował jako urzędnik państwowy. Po uzyskaniu habilitacji, której tytuł brzmiał Lichwa w nauce i prawie kościelnym do Soboru Wienneńskiego (Lwów 1926), podjął pracę na Wydziale Prawa Uniwersytetu Jana Kazimierza we Lwowie i tam uzyskał w 1936 roku tytuł profesora nadzwyczajnego i kierował Katedrą Prawa Kościelnego ${ }^{6}$.

W okresie międzywojennym Halban czynnie uczestniczył w życiu Kościoła katolickiego w Polsce. Nie zajmował się więc historią tej instytucji jako badacz jej funkcjonowania od strony ściśle tylko prawnej, ale był on zaangażowanym członkiem wspólnoty kościelnej, do której przynależał. Uczestniczył między innymi jako członek Komitetu Wykonawczego w Pierwszym Krajowym Kongresie Eucharystycznym w Poznaniu, który odbył się w dniach 26-29 czerwca 1930 roku? Podczas jego obrad wygłosił referat Eucharystia źródtem petni życia jednostki ${ }^{8}$. Uczestniczył też w ramach Akcji Katolickiej w archidiecezji lwowskiej w wielu inicjatywach tej organizacji, propagując między innymi podczas licznych odczytów katolicką naukę społeczną.

W czasie drugiej wojny światowej, poszukiwany przez Niemców za przedwojenną krytykę narodowego socjalizmu w swoich publikacjach, ukrywał się we lwowskim klasztorze katolickim. W 1945 roku przyjechał do Lublina i podjął pracę na Wydziale Prawa i Nauk Społeczno-Ekonomicznych KUL, przez krótki czas w 1949 roku — będąc jego dziekanem ${ }^{9}$. Po zlikwidowaniu przez władze komu-

areigenthums, t. 1. Grundlagen, Innsbruck 1894; idem, Das römische Recht in den germanischen Volkstaaten: ein Beitrag zur deutschen Rechtsgeschichte, t. 1-2, Breslau 1899; Zur Geschichte des deutschen Rechtes in den Gebieten von Tschernigow und Poltawa: archivalischer Reisebericht, Weimar 1898.

6 A. Redzik, Wydział Prawa Uniwersytetu Lwowskiego w okresie Drugiej Rzeczypospolitej $i$ w czasie II wojny światowej, „Prace Komisji Historii Nauki. Polska Akademia Umiejętności” 10, 2010, s. 139.

7 E. Nawrot, Pierwszy Krajowy Kongres Eucharystyczny w Polsce, Wrocław 1997, s. 30.

8 Ibidem, s. 86.

9 L. Ćwikła, Leon Halban (1893-1960), [w:] Dziekani Wydziału Prawa, Prawa Kanonicznego i Administracyjnego Katolickiego Uniwersytetu Lubelskiego Jana Pawła II, Lublin 2008, s. 73 79; zob. także W. Szwarc, Halban Leon, [w:] Stownik biograficzny miasta Lublina, red. T. Radzik, J. Skarbek, A.A. Witusik, Lubin 1995, s. 105-106. 
nistyczne Wydziału Prawa KUL związał się z Wydziałem Prawa UMCS, gdzie do śmierci wykładał i był kierownikiem Katedry Historii Powszechnej Państwa i Prawa ${ }^{10}$. Należał do wielu towarzystw naukowych i czynnie uczestniczył w ich działalności. Był między innymi członkiem Lubelskiego Towarzystwa Naukowego (wiceprezes), Polskiego Towarzystwa Historycznego (prezes oddziału lubelskiego), Polskiego Towarzystwa Ludoznawczego (wiceprezes zarządu) ${ }^{11}$. Zmarł 3 maja 1960 roku w Lublinie.

\section{Dorobek naukowy Leona Halbana}

W dorobku L. Halbana znalazło się kilkadziesiąt publikacji o charakterze naukowym i popularnonaukowym, dotyczących dziejów prawa kościelnego i świeckiego, filozofii religii oraz bieżącej problematyki kościelnej, a przede wszystkim religijności niemieckiej ${ }^{12}$. Za najbardziej wartościowe poznawczo i naukowo uznać należy: Zasady społeczne nowego prawa kościelnego: próba syntezy, Poznań 1922; Powstanie i rozwój zapowiedzi matżeńskich w wiekach średnich, Lwów 1925; Lichwa w nauce i prawie kościelnym do Soboru Wienneńskiego (1311 r.), Lwów 1926; Supremacja państwa nad Kościotem, Lwów 1927; Społeczne ideaty chrześcijaństwa w pierwszych wiekach, Poznań 1929; Znaczenie nieznajomości prawa w kanonistyce, Lwów 1929; Eucharystia źródtem petni życia jednostki, Lwów 1930; Historyczne podstawy Akcji Katolickiej, Lwów 1930; Pakta Lateraneńskie, Warszawa 1931; Encyklika z dnia 15 maja 1931 o sprawach społecznych, Lwów 1932; Zanik supremacji państwa nad kościołem w Niemczech, Lwów 1933; Religia w Trzeciej Rzeszy, Lwów 1936; Na straży ducha i kultury, Płock 1938; O jedności moralnej świata, Lwów 1938; Wczesne chrześcijaństwo w stosunku do państwa na tle ogólnej katolickiej nauki o państwie, Warszawa 1938; Własność podstawa wolności, Lwów 1939; Mistyczne podstawy narodowego socjalizmu, Lublin 1946, wyd. drugie, Lublin 1948; Charakterystyka ideału społecznego Dekretu Gracjana, Lublin 1948; Religia starogermańska i jej aktualne znaczenie w Niemczech, Lublin 194913; Znaczenie zwyczajów prawnych i ich badanie, Poznań 1952.

10 W. Witkowski, Lubelscy historycy prawa: Leon Halban, Witold Sawicki i Józef Mazurkiewicz, [w:] Prawo, kultura, uniwersytet. 80 lat ośrodka prawniczego KUL, Lublin 1999, s. 105-116.

11 J. Mazurkiewicz, Prof. dr. Leon Halban 1893-1960, „Rocznik Lubelski” 3, 1960, s. 332.

12 Znaczenie dorobku naukowego Halbana podkreśla zwłaszcza współcześnie Bogumił Grott. Badacz ten szczególnie docenia wartość dzieł uczonego poświęconych religijności niemieckiej w okresie Trzeciej Rzeszy, wskazując na konieczność powszechniejszego uwzględniania jego spuścizny naukowej. Zob. B. Grott, Profesor Leon Halban jako badacz neopogaństwa niemieckiego i prekursor politologii religii w Polsce (w czterdziesta piąta rocznicę zgonu), https://konserwatyzm. $\mathrm{pl}$ /profesor-leon-halban-jako-badacz-neopoganstwa-niemieckiego-i-prekursor-politologii-religii-w-polsce-w-czterdziesta-piata-rocznice-zgonu/ (dostęp: 15.05.2019).

13 Dwie publikacje omawianego autora zostały wydane ponownie w książce: Przedhitlerowskie korzenie nazizmu, czyli dusza niemiecka $w$ świetle filozofii i religioznawstwa, red. B. Grott, 


\section{Kościół, jego nauka i losy w Europie według nauki Leona Halbana}

Leon Halban wiele miejsca w swojej działalności naukowej i publicystycznej poświęcał Kościołowi katolickiemu i jego nauce. Zawsze był jego żarliwym obrońcą, a w jego doktrynie dostrzegał wiele pozytywnych cech, które dobrze wypłynęły na losy ludzkości i świata, zwłaszcza Europy. Zauważał, że Kościół nigdy nie potępia żadnych ustrojów społeczno-politycznych, które powoływane są do istnienia po to, aby w zmieniających się często warunkach historycznych i geopolitycznych służyć dobru człowieka i jego rozwojowi. W jednej ze swych publikacji stwierdzał: „Nie ma powodów sądzić, żeby Kościół nie chciał lub nie mógł godzić się ze zmianami w istniejącym ustroju, o ile tylko nie będą one zasadniczo sprzeczne z jego nauką i etyką"14.

W dziejach kościołów chrześcijańskich często się zdarzało, że były one podporządkowane państwu, którego władza nad całym zresztą społeczeństwem była absolutna i dotyczyła najdrobniejszych szczegółów jego życia i funkcjonowania. Tak było w Bizancjum, o którym Halban pisał: „bizantyjska omnipotencja państwa, podobnie jak współczesne totalitaryzmy, nie mogła zgodzić się na istnienie niezależnej władzy duchowej, której by przysługiwało ostatecznie prawo rozstrzygania w zakresie etyki i obyczajów"15. Problematyka związana z podporządkowaniem Kościoła państwu w cywilizacji bizantyńskiej była wówczas przedmiotem badań polskich uczonych. Spośród historyków dziejami Bizancjum i relacji tego cesarstwa do Kościoła chrześcijańskiego zajmował się między innymi Kazimierz Zakrzewski ${ }^{16}$, natomiast pogłębioną filozoficznie oraz opartą na obszernej faktografii ocenę stosunków religijnych w tym państwie przedstawił w swoich dziełach Feliks Koneczny.

W Niemczech doktryna bizantyńskiej omnipotencji państwa i prymatu jej nad jednostką znalazła swoich licznych zwolenników wśród filozofów, z których niewątpliwie największą popularność zyskał „urzędowy filozof” Prus Georg W. Hegel. Charakteryzując jego doktrynę, Halban pisał, że myśliciel ten

twierdził, że przez wojnę utrzymuje się moralne zdrowie narodów; tak jak ruch wiatrów strzeże morze przed zgnilizną. W logicznym związku pozostaje pogląd, że prawdziwa odwaga narodów kulturalnych polega na poświęceniu się w służbie państwa, bezwzględnym podporządkowaniu jednostki idei ogólnej, którą ono określa, ustanawia, czy wyznacza ${ }^{17}$.

O. Grott, Warszawa 2018. Są to: Mistyczne podstawy narodowego socjalizmu (ibidem, s. 73-119) oraz Religia starogermańska i jej aktualne znaczenie w Niemczech (ibidem, s. 121-189).

${ }^{14}$ L. Halban, Zasady społeczne nowego kodeksu Prawa Kościelnego. Próba syntezy, Poznań-Warszawa 1922, s. 38.

15 L. Halban, Konflikt papiestwa z cesarstwem jako walka o zdrowie moralne życia politycznego, Warszawa 1938, s. 10.

16 Zob. K. Zakrzewski, Historia Bizancjum, Warszawa 1938.

17 L. Halban, Mistyczne podstawy narodowego socjalizmu, Lublin 1946, s. 16. 
W Niemczech, ale też w innych krajach Europy Zachodniej od czasów nowożytnych, pod wpływem tendencji władz państwowych zmierzających do podporządkowania instytucji religijnych państwu, także w kościelnym kanonicznym prawie dochodzić zaczęło do zmian mających na celu realizowanie w praktyce kościelnej tej zasady. Jak pisze L. Halban,

od końca wieku XVI została najpierw we Francji skrystalizowana nowa zasada kanonistyczna, legalizująca rozwijający się już stanowczo w wieku XV tzw. gallikanizm. Trzeba powiedzieć, że ten kierunek zarówno w teorii, jak i w praktyce bierze stanowczo górę w wieku XVIII, także w niemieckich krajach katolickich. Poza tym co już powiedziano, nie tylko zrywa z uniwersalizmem, ale poddaje Kościół państwu i sprowadza go do roli, którą się określa: „Die Religion ein Teil der Staatspolizei”"18.

Kościół katolicki zaś jako instytucja zawsze był obrońcą osobistej wolności człowieka, jego podmiotowości i godności ${ }^{19}$.

Myśliciele starochrześcijańscy byli zwolennikami koncepcji głoszącej, że podstawowe prawa podmiotowe przysługują od poczęcia do naturalnej śmierci wszystkim ludziom, ale nie oznacza to bynajmniej, że wszystkie osoby należy traktować w życiu społecznym według tej samej, szablonowej miary. Istnieją bowiem naturalne różnice pomiędzy nimi, które w życiu indywidualnym oraz społecznym należy koniecznie uwzględniać. Co więcej, w myśli chrześcijańskiej podkreśla się, że im wyższy jest status społeczny jakiejś osoby, tym większe są jej obowiązki wobec innych ludzi i państwa. Halban pisał w związku z tym, że

tu właśnie zachodzi zasadnicza różnica zarówno między nierównością prawną pogańską, jak i współczesną zasadą równouprawnienia. Uważa się bowiem, że im doczesne stanowisko jednostki w społeczeństwie jest wyższe, obojętna, czy dzięki majątkowi, stopniowi wykształcenia, lub z innych względów, tym i obowiązki są większe, zarówno wobec bliźnich, jak i ogółu. Nadto w równym stopniu rośnie odpowiedzialność moralna i karna ${ }^{20}$.

Przeciwstawiając się rygorystycznemu rozstrzyganiu spornych spraw i problemów między ludźmi, Kościół głosił już od pierwszych wieków chrześcijaństwa zasadę, że

trudności i tarcia codzienne mogą być tylko unieszkodliwione, jeśli jako podstawę stosunku człowieka do człowieka przyjmie się czynną miłość bliźniego, która łączy i buduje, a nie nienawiść i drobiazgowe obstawanie przy swoich rzekomych prawach, które dzielą i burzą. W związku z tym i w konsekwencji przyjętego założenia musiano uznać i daleko idące obowiązki jednostki wobec bliźnich, niezależnie od ewentualnego wynagrodzenia w życiu doczesnym ${ }^{21}$.

18 L. Halban, Kilka uwag dotyczacych znaczenia naukowego i praktycznego prawa kościelnego, Lublin 1957, s. 16.

19 L. Halban, Własność podstawa wolności, Lwów 1939, s. 30.

20 L. Halban, Społeczne ideały chrześcijaństwa w pierwszych wiekach, Poznań [1929], s. 41.

${ }^{21}$ Ibidem, s. 70. 
W Europie jednak pod wpływem różnych ideologii wolnomyślicielskich nastąpiła laicyzacja życia społecznego, a sprawy duchowe człowieka zaczęły odgrywać coraz to bardziej marginalną rolę. Od czasów zwłaszcza XVIII wieku stosunek wielu Europejczyków do Kościoła katolickiego zaczął się powoli zmieniać — początkowo stawał się obojętny, z czasem zaś wielu ludzi zaczęło odchodzić od religii, hołdując racjonalizmowi, hedonizmowi i materialistycznej postawie życiowej. Indyferentyzm religijny, a nawet wrogość do religii zaczęły zataczać coraz to szersze kręgi, a pochopna ufność w siłę własnego rozumu i nauki, która miała zastąpić myślenie religijne człowieka, zaczęły przybierać na sile. L. Halban pisał:

W ciągu wieku XIX można było stwierdzić stały, z roku na rok silniej uwydatniony zanik poczucia, a zdawało się, że i potrzeby religii. Świadczą o tym literatura, sztuka, nauka i zachowanie się zarówno warstw najbardziej, jak i średnio i mniej wykształconych. Zapanowało przekonanie, uchodzące często za pewnik, że wielka rola religii w historii jest skończoną, gdyż ludzkość weszła w epokę, w której czynniki rozumowe i tak zwane praktyczne będą odgrywać rolę decydującą ${ }^{22}$.

Jak wiadomo, wielu myślicieli katolickich kryzysu religijności mieszkańców Europy zaczęło doszukiwać się w okresie odrodzenia, a nawet późnego średniowiecza, kiedy to wśród ówczesnych elit intelektualnych fascynowano się coraz bardziej pogańską filozofią antyku (zwłaszcza tą, której koncepcje Boga i człowieka były sprzeczne z doktryną chrześcijańską), bagatelizując zajmowanie się tradycją i kulturą katolicką. Proces ten znacznie się pogłębił za czasów reformacji, która zerwała instytucjonalną więź z Rzymem. Według Halbana jednak w wieku XIX na niespotykaną wcześniej skalę doszło do masowego i nieograniczonego tylko do inteligencji i niektórych krajów zachodniej Europy zjawiska odchodzenia od religii oraz upowszechniania się ateizmu zarówno teoretycznego, jak i praktycznego. Racjonalizm, tak popularny i propagowany przez filozofów francuskiego oświecenia w XVIII stuleciu, spopularyzowany w społeczeństwie, także w niższych jego warstwach, przyniósł wtedy obfite żniwo w czasach zwłaszcza pozytywizmu, przyczyniając się do upadku wiary i zaniku praktyk religijnych w wielu środowiskach, zwłaszcza inteligenckich.

\section{Istota religijności niemieckiej i jej najważniejsze cechy}

Racjonalizm znajdował swoich zwolenników wśród wielu przedstawicieli inteligencji niemieckiej, między innymi historyków i filozofów. Badania historyczne, w szczególności dotyczące dziejów religii, w niemieckiej nauce od dawna zresztą miały charakter zideologizowany i służyły nie bezinteresownemu odkrywaniu prawdy o przeszłości ludów germańskich, lecz ich celem było umocnienie świadomości narodowej i odrębności Niemców oraz wyartykułowaniu ich wyższości

22 L. Halban, Pakta Lateraneńskie, Warszawa 1931, s. 5. 
kulturowej i cywilizacyjnej w porównaniu z dorobkiem i osiągnięciami narodów słowiańskich i romańskich ${ }^{23}$. L. Halban stwierdzał, że

od początku niemal studia nad starożytnościami germańskimi pozostają w związku z dążeniami wyprowadzenia Niemiec ze szczególnie dotkliwego rozbicia państwowego i stworzenia w masach silnego poczucia jednolitości narodowej, w miejsce żywych lokalnych patriotyzmów. Z czasem nawet i to w postaci coraz bardziej stanowczej, a nieraz wprost jaskrawo krzykliwej będzie się upatrywać w religii starogermańskiej środek do stworzenia jednolitej religii i „duchowości” (Geistigkeit) Niemiec. Te zaś poczytuje się i poczytywało w pewnych bardzo zresztą szerokich kołach jako nieodzowne dla pełnej jedności narodowej ${ }^{24}$.

Wśród niższych warstw społeczeństwa niemieckiego przeważał prymitywny, zabobonny irracjonalizm ${ }^{25}$. Halban twierdził, że był on częstokroć związany $z$ upowszechnianym przez niemiecką inteligencję wrażeniem poczucia rzekomej „wyższości” rasy germańskiej nad innymi, głównie ludami słowiańskimi. Często też wiązał się z krytyką obiektywizmu w naukach humanistycznych i społecznych, którego możliwość istnienia podważano ${ }^{26}$.

W Niemczech oprócz nurtu racjonalistycznego od początku istnienia w nich chrześcijaństwa dużą rolę odgrywał nurt mistyczny, który przyjmował niekiedy bardzo odmienne oblicza; najczęściej znacznie różnił się od oficjalnej nauki katolickiego Kościoła, ponieważ głosił na przykład wiarę w preegzystencję niemieckiego narodu, apoteozę irracjonalizmu oraz panteizm ${ }^{27}$. Do klasyków średniowiecznej jeszcze mistyki niemieckiej sprzecznej z wiarą katolicką zaliczył L. Halban żyjącego w drugiej połowie XIII i w pierwszej połowie XIV stulecia Eckharta, którego poglądy w 1329 roku zostały potępione przez papieża Jana XXII; mimo to miał on wielu uczniów i zwolenników (w XIV wieku był nim między innymi Jan Tauler), a nawet szerzył się jego swoisty „kult”, trwający do czasów nam współczesnych.

Dla licznych swoich czcicieli w XIX i XX wieku jest Eckhart jedną z największych postaci w historii ducha germańskiego, a potępienie jego nauki przez Stolicę Apostolską podkreślano jako jeszcze jeden przykład dławienia nordycko-germańskiej duchowości przez niższo gatunkowy syryjsko-żydowsko-śródziemnomorski czy też rzymski czynnik ${ }^{28}$.

Zresztą, jak pisał uczony, od czasów starożytnych plemiona germańskie mimo pozornego niekiedy przyjmowania religii chrześcijańskiej praktykowały systematycznie odziedziczone po poprzednich pokoleniach pogańskie zwyczaje, sprzeczne

23 L. Halban, Religia w Trzeciej Rzeszy, Lwów 1936, s. 28.

24 L. Halban, Religia starogermańska i jej aktualne znaczenie w Niemczech, Lublin 1949, s. 7.

${ }^{25} \mathrm{~K}$. Mikoś, Ideologia volkistowska u źródet niemieckiego neopoganizmu, „Nomos. Kwartalnik religioznawczy" 2005, nr 51-52, s. 51-74.

${ }^{26}$ L. Halban, Religia starogermańska i jej aktualne znaczenie w Niemczech, s. 52.

27 Zob. podobną jak w tekstach L. Halbana interpretację współczesnych nam religiologów: P. Szuppe, Ideologia i mistyka volkistowska u źródet nazizmu, „Collectanea Theologica” 73, 2003, z. 2 , s. 87.

28 L. Halban, Mistyczne podstawy narodowego socjalizmu, s. 10. 
z duchem chrystianizmu, bo ze swej natury okrutne i bestialskie. „I tak na przykład Frankowie podług Prokopa w roku 539 wrzucają do rzeki kobiety i dzieci Gotów jako ofiarę pierwocin wojennych" 29 — pisał Halban. Jego pogląd na istotę i naturę religii germańskich odbiega od tych przedstawianych we współczesnej historiografii i badaniach religiologów, zwłaszcza niemieckich, na przykład Friedricha Wilhelma Haacka:

ruch neopogański i wynikające z niego myśli i działania to coś całkowicie autonomicznego, zbudowanego z pewnej idei, która jest całkowicie obca dawnej religii Germanów. Jest nią wiara w wyższość określonej rasy ludzkiej (właśnie germańsko-nordyckiej) nad innymi. Jeśli ktoś będzie szukał takiej wiary u dawnych Germanów (o ile pozwalają na to możliwości historyków), to nie ma szans jej znaleźć. Są to tylko pewnego rodzaju kalki nałożone na historyczną rzeczywistość Germanów, fałszujące ją ${ }^{30}$.

Zasadniczo jednak antychrześcijański nurt w niemieckiej myśli filozoficznej i społecznej, nasączony wspomnianym subiektywistycznym panteizmem i mistycyzmem, zaczął przeważać w społeczeństwie niemieckim w XIX stuleciu, i to on przyczynił się do tak radykalnego odejścia Niemców od europejskiego dziedzictwa kultury łacińskiej. Michał Musielak zauważa:

Ta charakterystyczna nieufność do rozumu i intelektualizmu jest zdaniem Halbana proweniencji dziewiętnastowiecznej, opartej na dorobku chrześcijańskim i naukach humanistycznych. Prądy pozytywizmu, materializmu czy filozofia Nietschego doprowadziły w Niemczech w końcu XIX w do zburzenia chrześcijańskich wartości, rzucając w konsekwencji wiele środowisk w objęcia kierunków mistycznych, neopogańskich. W nich należy szukać źródeł duchowości Trzeciej Rzeszy ${ }^{31}$.

W Niemczech racjonalizm oświeceniowy, tak charakterystyczny dla angielskiej i francuskiej kultury XVIII i XIX wieku, nie zakorzenił się tak mocno jak w innych krajach Zachodu, chociaż można zauważyć jego przejawy w twórczości niektórych teologów protestanckich tego kraju. W tamtejszym społeczeństwie przeważał bowiem sentymentalizm, który co prawda nie przeciwstawiał się racjonalistycznej krytyce teologii chrześcijańskiej, zwłaszcza katolickiej, ale bronił także irracjonalnych wierzeń ludowych, wywodzących się z czasów pogańskich. Wiązał się on z propagowaniem idei mesjanistycznych i mającego zjednoczyć rozbite politycznie Niemcy w jeden organizm państwowy mesjanizmu ${ }^{32}$. L. Halban pisał:

Zwalczanie dogmatów tradycyjnych kościołów, przenikanie racjonalizmu, zwłaszcza w tak wielkiej mierze do teologii protestanckiej wspierało istotnie usiłowania germańskości. [...] Przede wszystkim już w wieku XIX uwidacznia się negatywny stosunek do rozumu i ar-

29 L. Halban, Religia starogermańska i jej aktualne znaczenie w Niemczech, s. 44.

30 F.W. Haack, Neopoganizm w Niemczech. Powrót Wotana, religii krwi, ziem i i rasy, przeł. Ż. Bugajska-Moskal, Kraków 1999, s. 19.

31 M. Musielak, Nazizm w interpretacjach polskiej myśli politycznej okresu międzywojennego, Poznań 1997, s. 88.

32 M. Maciejewski, Ruch i ideologia narodowych socjalistów w Republice Weimarskiej. O źródłach i początkach nazizmu 1919-1924, Warszawa-Wrocław 1985, s. 188-190. 
gumentów rozumowych. Ich lekceważenie i przyznanie ostatecznie prymatu czynnikom emocjonalnym stało się jak wiadomo tak bardzo charakterystycznym dla Weltanschauung ${ }^{33}$.

Zdaniem Halbana Niemcy jako naród w ciągu wielu wieków swojej historii objawiali wiele negatywnych cech charakteru. Okrucieństwo starożytnych plemion germańskich w świetle analizy różnych źródeł pochodzących z czasów przed upowszechnianiem się na ich ziemiach chrześcijaństwa było wręcz odrażające. Wiązało się najczęściej z przyjmowaniem przez nich systemów wierzeń opartych na kulcie przemocy i związanych z tym bestialskich zachowań.

Pisarz bizantyjski Leon Diakon opowiada o Normanach w Państwie Wschodnio-Rzymskim, że podług zwyczaju ojczystego zwykli byli zarzynać większość jeńców wojennych i spalać ich razem ze swymi poległymi. Wierzyli bowiem, że w ten sposób zabici i spaleni pozostaną w życiu przyszłym niewolnikami ich towarzyszy. Sami zaś nie dawali się brać do niewoli lecz popełniali samobójstwo ${ }^{34}$.

Według Halbana prymitywne wierzenia starogermańskie utrzymywały się i utrzymują w Niemczech od czasów sprzed przyjęcia chrześcijaństwa. W dzisiejszych czasach sprzyja temu protestantyzm, a niektórzy jego przedstawiciele wykładający jego naukę jako teolodzy ex cathedra głoszą apoteozę pogańskiej moralności i mitologii, sprzeniewierzając się tym samym zasadom, które stały się fundamentem moralności opartej na Dekalogu i moralności Chrystusowej. Halban nazywał ten proceder uprawianiem swoistej, fałszywej „mistyki” germańskiej, opartej na kulcie i naśladownictwie takich zasad moralnych i zachowań, które deprawują człowieka i czynią go złym, nie zaś dobrym moralnie.

Szerokość zasięgu tej mistyki germańskiej, wrogiej wszelkiej obczyźnie, a w zakresie etyki wynoszącej jako cnoty wszelkie okropności Eddy i Nibelungów oraz oddźwięk, jaki ona znajduje w literaturze, w historiografii i filozofii, potęguje jeszcze fakt, że i teologia protestancka bardzo niedostatecznie tylko przed nią się broni. Niejeden z teologów przyjmuje przynajmniej częściowo pewne jej zasady, a nawet chociaż w tym stopniu jest to jeszcze rzeczą wyjątkowo w wieku XIX, spotykamy na katedrze teologii w uniwersytecie w Getyndze świadomego propagatora skrajnej religijności germańskiej w osobie Pawła de Lagarde (1827-1891) ${ }^{35}$.

Światopoglądy wywodzące się z neopogańskich religii starogermańskich zawsze zdaniem Halbana miały duże znaczenie w Niemczech, szczególnie wśród tamtejszych elit intelektualnych. W związku z tym uważał, że w Niemczech „religia posiada w systemie ekskluzywnego światopoglądu duże znaczenie. Możemy nawet od razu powiedzieć, że ten ostatni powstał i skrystalizował się na podstawie różnych kierunków sekciarskich, które pleniły się na długie lata przed wojną światową"36. Współczesny nam badacz Paweł Szuppe wskazywał, że zarówno

${ }^{33}$ L. Halban, Religia starogermańska i jej aktualne znaczenie w Niemczech, s. 52.

34 Ibidem, s. 62.

35 L. Halban, Mistyczne podstawy narodowego socjalizmu, s. 28.

${ }^{36}$ L. Halban, Narodowy socjalizm jako przejaw cywilizacyjny, [w:] Kultura i cywilizacja, praca zbiorowa, Lublin 1937, s. 292. 
myśl racjonalistyczna, jak i idealistyczny chrystianizm oraz neopoganizm „przeniknęły narodową strukturę, opanowując szerokie kręgi społeczeństwa niemieckiego przełomu XIX i XX w." ${ }^{37}$.

Antychrześcijańskie nurty religijne i kulturowe propagowane były przez uczonych niemieckich różnych specjalności. Zwłaszcza od XVIII wieku „ilość mniej lub więcej nieprawdopodobnych sekt, przede wszystkim w niemieckich krajach protestanckich, daleko zaś mniejsza w katolickich, wzrasta ustawicznie [...]"38. W XIX stuleciu wrogie chrześcijaństwu idee głosili historycy Felix Dahn, Heinrich von Eicken, Heinrich von Treitschke. Poglądy tego typu propagował także teolog Paweł Lagarde, który zarzucał kościołom chrześcijańskim „brak rysów męskich”39. Według niego Jezus nie był Mesjaszem, lecz tylko człowiekiem, który nie głosił bynajmniej uniwersalistycznie pojmowanej chrześcijańskiej miłości bliźniego. Był on zwolennikiem takiej religii, która preferowałaby wychowanie niemieckiego społeczeństwa w poczuciu nadzwyczajnej siły i wielkości, gdyby Zbawiciel urodził się i głosił swoje nauki w Niemczech, a nie na Bliskim Wschodzie. Lagarde postulował konieczność odrzucenia przez współczesne mu chrześcijaństwo Starego Testamentu oraz znaczne „oczyszczenie” Nowego Testamentu z elementów nieodpowiadających mentalności niemieckiego wyznawcy. Twierdził też, że katolicyzm i wiara kultywowana w średniowieczu krępowały autentyczny rozwój kultury niemieckiej ${ }^{40}$. Na poglądy jego powoływali się jeszcze przed pierwszą wojną światową wielokrotnie niemieccy neopoganie z Ludwikiem Fahrenkrogiem na czele. Zaprezentowany tu pogląd Halbana nie stracił na aktualności. Jak pokazują bowiem badania Aleksandry Kmak-Pamirskiej, która podobnie jak on stara się dociekać przyczyn szerzenia się neopogańskich i antychrześcijańskich ideologii w Niemczech w czasach Trzeciej Rzeszy:

proces powrotu do wierzeń pogańskich był widoczny w Niemczech XIX wieku, charakteryzujących się krytyką i odejściem od religii chrześcijańskiej [...]. Oczywiście teoretycy nacjonalistyczni jedyne rozwiązanie zaistniałej sytuacji widzieli w stworzeniu religii narodowej, która miała stanowić konglomerat religii chrześcijańskiej z ideologią nacjonalistyczną bądź miał to być nowy system religijny, odwołujący się do okresu germańsko-mistycznego ${ }^{41}$.

Do podobnych wniosków dochodzi Mateusz Maleszka ${ }^{42}$. Także deklarujący oficjalnie swoją nienawiść do chrześcijaństwa Friedrich Nietzsche cieszył się w Niemczech bardzo dużą popularnością w szerokich warstwach społeczeństwa.

L. Halban stwierdzał, że

37 P. Szuppe, op. cit., s. 101.

${ }^{38}$ L. Halban, Mistyczne podstawy narodowego socjalizmu, s. 7.

39 L. Halban, Narodowy socjalizm jako przejaw cywilizacyjny, s. 296.

40 G.L. Moose, Kryzys ideologii niemieckiej: rodowód intelektualny Trzeciej Rzeszy, przeł. T. Evert, Warszawa 1972, s. 52.

41 A. Kmak-Pamirska, Religia w czasach Trzeciej Rzeszy, Toruń 2010, s. 107.

${ }^{42}$ M. Maleszka, „O aryjskie chrześcijaństwo”. Próba syntezy chrześcijaństwa i rasistowskiego nacjonalizmu $w$ polemikach dziewiętnasto- $i$ dwudziestowiecznych autorów niemieckich, „Textus et Studia” 2015, nr 2, s. 69-86. 
Kto nie widział nieprawdopodobnych ilości egzemplarzy Nietzschego w tornistrach niemieckich żołnierzy wojny światowej, ten nie zdaje sobie sprawy, jaki olbrzymi wpływ wywierał ten, gardzący zresztą tak często Niemcami, filozof na szerokie sfery społeczeństwa. Można śmiało powiedzieć, że wśród roczników wojskowych inteligencji i półinteligencji, zwłaszcza protestanckiej, w latach 1914-1918 Nietzsche dominowat ${ }^{43}$.

Jego zdaniem w chrześcijańskim ruchu niemieckiego protestantyzmu (byli to między innymi tak zwani Niemieccy Chrześcijanie) w okresie od 1933 roku, kiedy to zaczął odgrywać on w Niemczech istotną rolę, coraz bardziej popularne stawały się poglądy niemieckich nacjonalistów ${ }^{44}$. Częściej też do głosu zaczęły dochodzić te środowiska protestanckich teologów, których przedstawiciele propagowali poglądy narodowosocjalistycznego ideologa Alfreda Rosenberga oraz Adolfa Hitlera. Celem Rosenberga, jak wiadomo, było stworzenie dla Niemców nowego, opartego na rasizmie światopoglądu, podporządkowanego interesom państwa oraz ,zapewnienie supremacji wybranemu narodowi, w imię wyższości krwi i rasy niemieckiej’45. Halban szczegółowo analizował poglądy wydanej przez niego w 1930 roku książki, która stała się jedną z podstawowych lektur i obowiązkowych młodego pokolenia Niemców w okresie panowania ideologii narodowego socjalizmu w ich państwie. Zasady, na jakich opierała się ideologia Rosenberga, można jego zdaniem w zwięzłej formie scharakteryzować jako ideologię będącą zlepkiem wcześniej już istniejących w niemieckim obszarze kulturowym doktryn, które łączyła fanatyczna wiara:

1. W wybraność ludu niemieckiego, którego przeznaczeniem jest władztwo nad innymi ludami;

2. przeświadczenie, że lud niemiecki jako taki został przed wiekami stworzony przez Opatrzność i wyposażony w najwyższe wartości duchowe, które mimo przeszkód przetrwały niezmienione, chociaż pod powłoką obcych kultur i wpływów narzuconych mu przemocą lub podstępem $^{46}$.

Według Halbana silna pozycja wodza III Rzeszy — Adolfa Hitlera — była nie tylko wynikiem zmiany ustroju, jaki dokonał się w tym kraju pod rządami narodowych socjalistów, ale także z wiary dużej części społeczeństwa niemieckiego w siłę i nadprzyrodzoną moc wybranego przez nich w demokratycznych wyborach przywódcy, którego postać niemalże deifikowano ${ }^{47}$. Z tym poglądem zgadzają się współcześni nam interpretatorzy i badacze religijności społeczeństwa niemieckiego w Trzeciej Rzeszy ${ }^{48}$.

43 L. Halban, Narodowy socjalizm jako przejaw cywilizacyjny, s. 294.

44 B. Grott, O. Grott, Wprowadzenie, [w:] Przedhitlerowskie korzenie nazizmu, s. 13.

45 Ibidem, s. 301.

${ }^{46}$ L. Halban, Mistyczne podstawy narodowego socjalizmu, s. 8.

47 M. Musielak, op. cit., s. 87.

48 A. Kmak-Pamirska, Elementy „religijne” w ideologii i obrzędach narodowosocjalistycznych Trzeciej Rzeszy, „Studia nad Autorytaryzmem i Totalitaryzmem” 34, 2012, nr 2, s. 37. 
W niemieckim społeczeństwie, którego mentalność kształtuje się pod wpływem bądź protestantyzmu, bądź neopoganizmu, następuje ustawiczny rozkład ideowy tamtejszej protestanckiej teologii, czego efektem jest dawno już rozstrzygnięta w katolicyzmie dyskusja na temat istoty Boga (spór między zwolennikami pojęcia Boga osobowego i panteizmu) i reakcji między Stwórcą a stworzeniem. Zwolenników niemieckiej wersji tejże pseudotelogii zyskuje coraz częściej pogański panteizm, a wśród zwolenników koncepcji Boga osobowego przeważa zaskakujący wprost katolika pogląd, że Bóg pragnie tylko pokoju między Nim a człowiekiem, natomiast walka między ludźmi o dominację rasową nie jest już grzechem, lecz nawet należy uznać ją za przejaw moralnej potęgi i patriotyzmu tych, którzy zwyciężają $^{49}$. Zdaniem L. Halbana rozkład religijno-moralny w Niemczech tuż przed drugą wojną światową był dowodem całkowitego niemalże odejścia tamtejszego społeczeństwa od religii Chrystusa i głoszonych przez niego zasad postępowania ludzi w życiu zarówno indywidualnym, jak i przede wszystkim społecznym:

nie wiadomo, czy w Niemczech uda się stworzenie nowej jednolitej religii. Na razie, poza podkreślonymi tutaj wspólnymi zasadami, chaos i rozbieżności są nieprawdopodobne. Ale już dzisiaj, patrząc na miliony w szeregach Niemieckich Chrześcijan i in., oraz na przeszło czteromilionową rzeszę zorganizowaną w ramach różnych ugrupowań neopogańskich, możemy stwierdzić zastraszającą wzrastającą dechrystianizację $e^{50}$.

L. Halban pisał, że wielu uczonych zastanawia się, jak możliwe było, że naród tak wybitnych i wrażliwych na piękno ludzkiego ducha, tak zasłużonych dla światowej kultury pisarzy, poetów i filozofów, mógł stać się podatny na ideologię pogańskiego, brutalnego i krwiożerczego narodowego socjalizmu. Pytanie to, jego zdaniem, jest niewłaściwie sformułowane z tego powodu, że tacy ludzie, jak Goethe, Schiller, Herder, Kant, „reprezentują [...] tylko aspiracje duchowe znikomej mniejszości, a obok drobnego Wejmaru, który usiłuje obdarzyć Niemców wielką, uniwersalistyczną treścią duchową, wznoszą się i potężnieją groźne Poczdam i Berlin, symbole zgoła innych ideałów" $"$.

\section{Neopogaństwo niemieckie a postawa katolików - wnioski na przyszłość}

Negatywne tendencje w pojmowaniu religii i religijności współczesnego człowieka, zdaniem L. Halbana, zarówno w Europie Zachodniej, zwłaszcza w Niemczech, jak i w Rosji, gdzie zapanowała bezbożna ideologia bolszewicka, powinny skłonić wszystkich zwolenników cywilizacji chrześcijańskiej, zwłaszcza katolików, do zwiększenia aktywności w obronie wiary i moralności opartej na uniwer-

49 A. Kmak-Pamirska, Religia w czasach Trzeciej Rzeszy, s. 109, 115.

${ }^{50}$ L. Halban, Narodowy socjalizm jako przejaw cywilizacyjny, s. 304.

51 L. Halban, Mistyczne podstawy narodowego socjalizmu, s. 21. 
salistycznych zasadach Dekalogu ${ }^{52}$. Odpowiedzialność moralna za obronę wartości chrześcijańskich przed zalewem neopogaństwa i sekciarstwa ciąży również na polskim narodzie. Jak zauważył uczony, sytuacja geopolityczna, w jakiej znalazła się Polska, „stawia nas wobec poważnego zadania wszechstronnego wzmacniania świadomości chrześcijańskiej Rzeczypospolitej, która przypada dzisiaj, podobnie jak w wieku XVI, obrona Krzyża wobec przeciwników ze Wschodu i nowinkarzy z Zachodu" 53 .

Należy pogłębiać naszą wiedzę katolicką i propagować jej zasady we wszystkich warstwach społecznych. Kościół dla naszego dobra przeciwstawia się bowiem zarówno kolektywistycznej, jak i liberalno-kapitalistycznej koncepcji wolności i własności, tak popularnych w społeczeństwie radzieckim i niemieckim. Kolektywizm zakłada, że własność środków produkcji oraz kapitał powinny należeć do państwa, natomiast liberalizm głosi koncepcję, że własność prywatna powinna należeć do osób prywatnych i jej używaniu nie powinno się stawiać żadnych prawnych ograniczeń. W warunkach kapitalistycznej konkurencji brak kontroli nad używaniem własności prywatnej oraz związana z tym faktem eliminacja jednostek słabych gospodarczo przyczynia się do ograniczenia wolności obywatelskiej:

W systemie liberalno-kapitalistycznym, wobec koncentracji dyspozycji środkami materialnymi w stosunkowo nielicznych rękach, wolność coraz liczniejszych najemników, tak fizycznych, jak i umysłowych, musi ulegać coraz dotkliwszym ograniczeniom. Ostatecznie pozostaliby wolnymi tylko członkowie kapitalistycznej elity ${ }^{54}$.

W Niemczech taką elitą byli zwolennicy skrajnego neopogańskiego rasizmu, wrogowie wiary i moralności katolickiej. Także w innych krajach katolicka nauka społeczna była i jest zagrożona. Jak wiadomo, zasada supremacji państwa nad Kościołem była skutecznie realizowana już od czasów średniowiecza we Francji.

Obok względów ideowych, podniesienia na zewnątrz blasku i niezależności korony francuskiej, legiści wysuwali jeszcze i inne motywy, a mianowicie konieczność chronienia Francji przed zubożeniem, grożącym z powodu wysyłania rok rocznie, z różnych tytułów, znacznych kwot do Rzymu. Ten argument trafiał do przekonania zarówno królowi, duchowieństwu, szlachcie i mieszczaństwu. Nie mniej popularnym było żądanie ograniczenia, względnie nawet zniesienia apelacji od wyroków sądów duchownych we Francji, do kurii. Zgadzało się z życzeniami biskupów, których samodzielność tym samym wzrastała, a także i zainteresowanych stron, zmuszonych do szukania sprawiedliwości w Rzymie, co było połączone z wielkimi trudnościami i kosztami ${ }^{55}$.

Również propagowana w późniejszych czasach przez wielu teoretyków państwa i prawa innych państw zachodnioeuropejskich nauka van Espena dotycząca stosunków prawnych między państwem a Kościołem, jak pisał L. Halban,

\footnotetext{
${ }^{52}$ L. Halban, Na straży ducha i kultury, Płock 1938, s. 16-17.

53 L. Halban, Narodowy socjalizm jako przejaw cywilizacyjny, s. 305.

54 L. Halban, Własność podstawa wolności, s. 29.

55 L. Halban, Supremacja państwa nad Kościołem. Nauka van Espena, Lwów 1927, s. 29-30.
} 
jest jasna i zrozumiała. Urzędnicy z powodu wszelkich swoich czynności odpowiadają przed królem. Nikt nie jest powołany do oceniania ich postępków. Jeśli naruszyli przepisy, należy ich zaskarżyć przed monarchą. Inaczej rzecz się przedstawia, jeśli ten ostatni jest winnym pośrednio lub bezpośrednio. Ponieważ nie ma on przełożonego, a in spiritualibus Kościół posiada władzę samodzielną, należy uznać możliwość pociągnięcia go do odpowiedzialności. Oczywiście środki karne, jakie mogą być zastosowane, są wyłącznie natury duchowej i nie mają znaczenia w dziedzinie temporaliów, praw i prerogatyw świeckich korony, nie podlegających Kościołowi ${ }^{56}$.

Halban uważał, że supremacja państwa nad Kościołem w wielu krajach, które tę zasadę zrealizowały i utrwaliły w postaci odpowiednio skonstruowanego prawodawstwa oraz związanych z tym procedur i zachowań osób świeckich — zwłaszcza tych sprawowujących wyższe urzędy państwowe — w stosunku do duchowieństwa, źle wpłynęła na kształtowanie się relacji społecznych tam, gdzie obowiązywała:

Otóż okazuje się, że najpierw we Francji, a z biegiem XVIII i XIX wieku i w innych państwach, ten system wyrządził poważne szkody. Wpłynął bowiem na znaczną dezorganizację Kościoła, w szeregach duchowieństwa powodował często wprost gorszące objawy, obniżenie koniecznego poziomu duchowego i zeświecczenie. Równolegle możemy zauważyć silne zobojętnienie w stosunku do wiary. Upaństwowiony kościół nie wzbudza już zaufania wśród sfer myślących i wykształconych, które go lekceważą, ani wśród mas, których sprawy i potrzeby mało na ogół mało na ogół interesują, wysokie, oglądające się na łaskę dworów, duchowieństwo. Uzależnienie od państwa, powoduje więc podobne objawy, jak w krajach prawosławnych ${ }^{57}$.

W świetle tych słów jego apel o obronę katolickich zasad moralnych i nauki społecznej Kościoła wydaje się tym bardziej istotny.

Halban, badając relacje między państwem a Kościołem oraz mentalność Europejczyków, uważał jednocześnie, że badania uczonych katolickich nie powinny ograniczać się do śledzenia religijności i poglądów filozoficzno-prawnych społeczeństw europejskich. Wskazywał on także na konieczność podejmowania badań etnosocjologicznych nad religijnością ludów pozaeuropejskich oraz jej wpływu na tworzenie się prawa zwyczajowego. Uważał, że religia odgrywa dosyć dużą rolę w powstawaniu norm moralnych w różnych społeczeństwach, chociaż mają na nie wpływ także i inne czynniki, takie jak na przykład ekonomiczne, polityczne czy geograficzne. Istnieje także sytuacja odwrotna, czyli dosyć znaczna siła oddziaływania wspomnianych czynników na samą religijność mieszkańców jakiegoś kraju.

\section{Bibliografia}

\section{Publikacje Leona Halbana}

Kilka uwag dotyczacych znaczenia naukowego i praktycznego prawa kościelnego, Lublin 1957. Konflikt papiestwa z cesarstwem jako walka o zdrowie moralne życia politycznego, Warszawa 1938.

\footnotetext{
56 Ibidem, s. 51.

57 Ibidem, s. 123-124.
} 
Mistyczne podstawy narodowego socjalizmu, Lublin 1946.

Na straży ducha i kultury, Płock 1938.

Narodowy socjalizm jako przejaw cywilizacyjny, [w:] Kultura i cywilizacja. Praca zbiorowa, Lublin 1937.

Pakta Lateraneńskie, Warszawa 1931.

Religia w Trzeciej Rzeszy, Lwów 1936.

Religia starogermańska i jej aktualne znaczenie w Niemczech, Lublin 1949.

Społeczne ideały chrześcijaństwa w pierwszych wiekach, Poznań [1929].

Supremacja państwa nad Kościotem. Nauka van Espena, Lwów 1927.

Własność podstawa wolności, Lwów 1939.

Zasady społeczne nowego kodeksu Prawa Kościelnego. Próba syntezy, Poznań-Warszawa 1922.

\section{Literatura pomocnicza}

Ćwikła L., Leon Halban (1893-1960), [w:] Dziekani Wydzialu Prawa, Prawa Kanonicznego i Administracyjnego Katolickiego Uniwersytetu Lubelskiego Jana Pawła II, Lublin 2008.

Grott B., Profesor Leon Halban jako badacz neopogaństwa niemieckiego i prekursor politologii religii w Polsce (w czterdziesta piata rocznicę zgonu), https://konserwatyzm.pl/profesor-leon-halban-jako-badacz-neopoganstwa-niemieckiego-i-prekursor-politologii-religii-w-polsce-w-czterdziesta-piata-rocznice-zgonu/.

Grott B., Grott O., Wprowadzenie, [w:] Przedhitlerowskie korzenie nazizmu, czyli dusza niemiecka w świetle filozofii i religioznawstwa, red. B. Grott, O. Grott, Warszawa 2018.

Haack F.W., Neopoganizm w Niemczech. Powrót Wotana, religii krwi, ziem i i rasy, przeł. Ż. Bugajska-Moskal, Kraków 1999.

Kmak-Pamirska A., Elementy „religijne” w ideologii i obrzędach norodowosocjalistycznych Trzeciej Rzeszy, „Studia nad Autorytaryzmem i Totalitaryzmem” 34, 2012, nr 2.

Kmak-Pamirska A., Religia w czasach Trzeciej Rzeszy, Toruń 2010.

Maciejewski M., Ruch i ideologia narodowych socjalistów w Republice Weimarskiej. O źródłach i poczatkach nazizmu 1919-1924, Warszawa-Wrocław 1985.

Maleszka M., „, O aryjskie chrześcijaństwo”. Próba syntezy chrześcijaństwa i rasistowskiego nacjonalizmu w polemikach dziewiętnasto- $i$ dwudziestowiecznych autorów niemieckich, „Textus et Studia" 2015, nr 2.

Mazurkiewicz J., Prof. dr. Leon Halban 1893-1960, „Rocznik Lubelski” 3, 1960.

Mikoś K., Ideologia volkistowska u źródeł niemieckiego neopoganizmu, „Nomos. Kwartalnik religioznawczy" 2005, nr 51-52.

Moose G.L., Kryzys ideologii niemieckiej: rodowód intelektualny Trzeciej Rzeszy, przeł. T. Evert, Warszawa 1972.

Motyka K., Socjologizujacy prawnicy: Czesław Martyniak, Zdzisław Papierkowski, Leon Halban, [w:] Pomiędzy etyka a polityka. 80 lat socjologii na Katolickim Uniwersytecie Lubelskim (1918-1998), Lublin 1999.

Musielak M., Nazizm w interpretacjach polskiej myśli politycznej okresu międzywojennego, Poznań 1997.

Nawrot E., Pierwszy Krajowy Kongres Eucharystyczny w Polsce, Wrocław 1997.

Przedhitlerowskie korzenie nazizmu, czyli dusza niemiecka $w$ świetle filozofii i religioznawstwa, red. B. Grott, O. Grott, Warszawa 2018.

Redzik A., Wydziat Prawa Uniwersytetu Lwowskiego w okresie Drugiej Rzeczypospolitej i w czasie II wojny światowej, „Prace Komisji Historii Nauki. Polska Akademia Umiejętności” 10, 2010.

Szuppe P., Ideologia i mistyka volkistowska u źródet nazizmu, „Collectanea Theologica” 73, 2003, nr 2.

Studia nad Autorytaryzmem i Totalitaryzmem 41, nr 3, 2019

(C) for this edition by CNS 
Szwarc W., Halban Leon, [w:] Stownik biograficzny miasta Lublina, red. T. Radzik, J. Skarbek, A.A. Witusik, Lubin 1995.

Widacki J., Szkice z dziejów prawa karnego i kryminologii w Krakowie. Myśli i ludzie, Kraków 2014.

Willaume J., Działalność naukowa Leona Halbana, „Biuletyn Lubelskiego Towarzystwa Naukowego" $1,1961$.

Witkowski W., Lubelscy historycy prawa: Leon Halban, Witold Sawicki i Józef Mazurkiewicz, [w:] Prawo, kultura, uniwersytet. 80 lat ośrodka prawniczego KUL, Lublin 1999.

Zakrzewski K., Historia Bizancjum, Warszawa 1938.

\section{THE CATHOLIC CHURCH AND GERMAN NEOPAGANISM \\ IN LEON HALBAN'S THOUGHT}

\section{Summary}

This article presents the views of Leon Halban referring to the problems of German religiosity. In the first part of the article, the family and the character and the academic achievements of this scholar were characterized. In the next part of the article, his views on the role of the Catholic Church in European culture were analyzed and his position in which he made a critical assessment of German religiosity was presented. Halban assumed that the Christianity practiced by Germans since the Middle Ages did not result from their authentic conversion. The Germans were often religiously indifferent and tended to fall into various heresies and deviations from faith. They also sought to achieve supremacy of the state over the Church in public life and law. Halban argued that a renewal of morality can only be achieved in the Catholic Church, whose ethical principles and doctrine should be propagated and applied in everyday life.

Keywords: German religiousness, history, Nazism, neopoganism, Catholic Church, state.

Ryszard Polak

ryszardpolak-ap@o2.pl 